\title{
The Mediating Effect of Organizational Commitment on the Relationship between Work-life Balance and Intention to Leave: Evidence from Working Women in Jordan
}

\author{
Hanan M. Al Momani ${ }^{1}$ \\ ${ }^{1}$ Department of Business Administration, Yarmouk University, Irbid, Jordan \\ Correspondence: Hanan M. Al Momani, Department of Business Administration, Yrmouk University, Irbid, \\ Jordan.
}

Received: March 28, 2017

Accepted: May 2, $2017 \quad$ Online Published: May 18, 2017

doi:10.5539/ibr.v10n6p164

URL: https://doi.org/10.5539/ibr.v10n6p164

\begin{abstract}
The aim of this study is to examine the mediating effect of organizational commitment on the relationship between work-life balance and intention to leave. The study population consists of (800) working women in King Abdullah University Hospital (KAUH). To collect the primary data a questionnaire survey was distributed to (200) working women, from them (144) questionnaires were returned. The study used linear regression and path analyses to test hypotheses. The study findings revealed that; there is a significant relationship between work-life balance and intention to leave, there is a significant relationship between work-life balance and (affective, continuance and normative) commitment, but not with continuous commitment, there is a significant relationship between (affective, continuance and normative) commitment and intention to leave. Finally, affective commitment fully mediates the relationship between work-life balance and intention to leave, while normative commitment partially mediates the relation. In light of these findings, the study recommends; adoption of the work-life balance program in Jordanian hospitals to improve the commitment of working women, and encourages Jordanian organizations to enhance the participation of employee in decision making and locus of control to improve organizational commitment.
\end{abstract}

Keywords: intention to leave, organizational commitment, work-life balance

\section{Introduction}

Today, women occupy an important position in modern societies and contribute effectively in advancing and developing their countries' economy. Women have become a key partner of success in their organizations. However, they face a big challenge due of their roles at work and home, they should do their best at work and taking care their families when baking home. According to Ramos et al. (2015), work-family issues significantly impacts employees' quality of life and their workplace.

However, the work boundaries are changing rapidly. Nature of business, social structure and pace of globalization have changed the approaches towards the business. Organizations are required in the modern countries to perform their services in $24 \times 7$ hours. This creates ultimate pressures on employees which came from increasing and extending working hours. This pressure results imbalance in the personal life of the employees. Incompatibility between career responsibilities and the home obligations create stress and pressure, especially among women that take home responsibilities their main priorities.About $40 \%$ of women married to partners they don't have adequate earning opportunities (Khatri et al., 1999). So they work for the purpose of improving the financial situation of the family (Hattar-Pollara \& Dawani, 2006). Many of the problems began to appear in most of the families in which both husband and wife are working due to the fatigue experienced by women. Most studies have indicated that working mothers are more vulnerable to conflict than non-working mothers (Biller, 1993).

The conflict between work and family life is "a form of conflict between the roles where pressures in work and family life are not compatible with each other in some respects (Lyness \& Judiesch, 2008). So, the participation in the work or family role will be more difficult as a result of participating in the role of the family or work (Greenhaus \& Beutell, 1985).

Because of this, women made strides to have a more flexible treatment in the workplace in terms of working 
hours and the establishment of units for the care of children in the workplace and work-sharing arrangements; but they still face social pressure to comply with standards that force them to be ideal mother and ideal employee and so on a daily basis (Hattar-Pollara \& Dawani, 2006). According to Kaur (2004), there is a growing trend for women to leave the work at marriage and the birth of children to take care of their husband and children in Asian countries. Women working in the Middle East are not an exception to the rule, the perfect balance between work and personal life remains the most important challenge faced by women as they are first responsible for the welfare of their families and care for their children (Abu Raddaha et al., 2012).

Hence, this study came to highlight the impact of work-life balance practices on intention to leave through organizational commitment among Jordanian women working in King Abdullah University Hospital (KAUH).

\subsection{Research Problem and Research Questions}

Labor market in Jordan is described as unfriendly women environment. Jordan was ranked No. 140 out of 142 countries in the global gender gap report as the rate of the gender participating in the Jordanian labor market is $14 \%$ women against $66 \%$ of men. Most of those working women (95\%) concentrated in three economic sectors out of thirteen which are: education and health; social work and public administration (Tamkeen fields for aid, 2015). These figures, logically, can indicate that much attention should be posed to working women, especially in the health sector which seeks to achieve the superior position in the Middle East region, as those unemployed women will become waste potentials.

More specifically, three reasons can be outlined for increasing attention and studying work-life balance: First, technological advances focus on achieving flexibility in workplace and pressures faced by the employees at work (Guest, 2001).Second, due to the great growth of - in particular - female employees who are married and have children there is an increased research attention on how these families balance between work and family roles and how these roles influence each other (Tatman, 2001). Finally, work values and attitude are changing with younger generations putting less importance on their career and more interest to achieving a balance between work-life and personal-life (Sturges \& Guest, 2004).

Thus, the study seeks to answer questions that were formulated as follows:

1. Does the work-life balance influence intention to leave among working women in KAUH?

2. Does the work-life balance influence organizational (affective, continuance and normative) commitment among working women in KAUH?

3. Does the organizational (affective, continuance and normative) commitment influence intention to leave for employee among working women in KAUH?

4. Does the organizational (affective, continuance and normative) commitment mediate the relationship between work-life balance and intention to leave among working women in KAUH?

\subsection{Significance and Contribution}

The significant of this study derived from the importance of the topic "the practice of work-life balance and its impact on intention to leave among working women". The main factor that leads to success of women in their work is the ability of achieving balance between family obligations and work demands. The failure to achieve this balance will negatively influence their duties towards home and work, which lead them to leave their job.

Moreover, the conflict between work and family is considered as an important issue for organizations and individuals due to its association with negative results for both (Lyness \& Judiesch, 2008). For example; increased absenteeism and labor force turnover, low performance in the work place, and poor physical and mental health (Lakshmi \& Gopinath, 2013). Add to this, all organizations try to retain their employees, as losing them means losing competent and knowledge or more specifically the competitive advantage that came from the tacit knowledge. Medical field is the most field where tacit knowledge is considered very important for effe ctive service (Aamir et al., 2016).

However, certain female pre-dominant occupations such as; nurses and teachers, does not afford to offer flexible operating rights as part-time or varying time schedule, they are not supported in these positions. Cultural, social norms and perceptions play an important role in the evolution or failure of the flexible working, the reason being the prejudice purpose, which might be solved through the legislative means if already available or can be created.

One important challenge face healthcare services is sustaining workforce, as the increasing trend in the population worldwide increasing the demand for healthcare (Aamir et al., 2016). For this reason, current studies in the health industry are paying attention to how to address the high cost of labor turnover and staff shortage 
(Chaaban, 2006). According to (Strachota et al., 2003), the cost of replacing one hospital nurse has been estimated to be around $\$ 42,000$ in Canada.

Despite of the significance of work-life balance, little attention is paid to this issue in the Arab world. A limited number of studies have been conducted in Arab countries (include Jordan) to investigate the effect of work-life balance on intention to leave among working women. Therefore the current study is carried out to fill the gap in literature by investigating the impact of work-life balance on intention to leave and investigating the mediating effect of organizational commitment on the relationship between work-life balance and intention to leave in KAUH.

Therefore, the theoretical and practical importance of the study centered on the following points:

1. The study provides some valuable insights on organizational commitment and intention to leave among working women in KAUH.

2. The study seeks to provide some knowledge to enrich the Arabic library and literature, which is a starting point for new studies.

3. The content also may be of an interest to academic studies to fill the gap in the literature by focusing on issues related to working women in Jordan.

4. The study findings can help managers in the reporting and decision making concerning knowledge management practices.

\section{The Objectives of This Study}

The following specific objectives are set for this study:

1. Identify the influence of work-life balance on intention to leave among working women in KAUH.

2. Identify the influence of work-life balance on organizational (affective, continuance and normative) commitment among working women in KAUH.

3. Identify the influence of organizational (affective, continuance and normative) commitment on intention to leave among working women in KAUH.

4. Identify whether the organizational (affective, continuance and normative) commitment mediates the relationship between work-life balance and intention to leave.

In conclusion, it can be said that a few studies have been conducted, considered all these three terms together. However, they did not focus on female worker separately. In addition, most of the studies were based onwestern developed countries. Thus, this study, which focused on female workers in Jordan, is different from these studies as it aims to examine the relationship between work-life balance and intention to leave through organizational commitment among working women in KAUH.

\section{Literature Review}

\subsection{Theoretical Framework and Research Hypotheses}

\subsubsection{Work-life Balance}

Work-life balance concept has caught fire in recent years, both in understanding and in public awareness. The media, consultants and employers show a high level of interest in the policies of work-life balance. Moreover, it has observed high growth in academic areas as well as other disciplines, which include; psychology, health, human resource management, industrial relations, sociology, feminism, social policy, and economics (Shankar \& Bhatnagar, 2010).

Various researchers defined work-life balance in various ways. For example, Clark (2001) defines work-life balance as a sense of satisfaction and accomplishment, what is required in the workplace and home better without conflict or overlap between roles. According to Felstead et al. (2002) work-life balance is "the relationship between cultural and institutional spaces and times of work and non-work in civilizations where income is primarily created and distributed through labor markets". Whereas, Voydanoff (2005) defines work-family-balance as "a global assessment that work and family resources are sufficient to meet work and family demands such that participation is effective in both domains".

Another definition of the work-life balance was introduced by the Rigby and O'Brien-Smith (2010) that work-life balance is a split of time between the work and personal life based on the priorities. In this definition, there are clear indication between the time management for both lives, one is personal life and other is official life. The priorities of the people may be different based on their perceptions, but the main thing is the consideration of both 
lives rather just focusing on the single one. Because if the focus is shifted to the single side of the life only, it is likely that balance would go out and effectiveness of the life may be compromised (Owusu-Poku, 2014).The balance between the work and life is essential for health and happy life, because extra time spend on the work leads to work stress and extra time spend at home leads to the unsuccessful life.

\subsubsection{Organizational Commitment}

The concept of the organizational commitment has taken a considerable importance over years and become an essential feature of the researches that are concerned with employees and organizations.

There are several definitions being introduced about organizational commitment. According to (Allen \& Meyer,1990) organizational commitment is a psychological state that combines an employee to an organization that lead to reduce the turnover of employees. While (Meyer \& Herscovitch ,2001) defined the organizational commitment as a multidimensional approach in nature which intends to analyze the attitude of the employee for the achievement of the organizational goals in addition to the membership's willingness. Also, it has been defined as a strong belief and acceptance of organization goals and principles with good performance and a strong desire to stay in the organization (Elizur \& Koslowsky, 2001).

As per the analysis of all these definitions presented above, there are several things which are common among these definitions. One important factor, is the commitment of the employee to stay in the organization for a longer period of time by providing a quality work with continuity. The other thing is the goal of the organization and goal congruence. Organizational goals are the aims of the organizations, but the goal congruence is basically the unity of goals, the goal of the employee and of the organization (Vigoda and Cohen, 2003). This means that employees act in such a way that their goals are also attached to the goals of the organizations.

\subsubsection{Organizational Commitment Models}

\subsubsection{Affective Commitment}

According to Meyer and Allen (1997) affective commitment is "the employee's emotional attachment to identification with and involvement in the organization". Affective commitment has been linked to positive work-related behaviors like organizational citizenship behavior (Meyer et al., 2002). Affective commitment model is linked with the wish of the employee to stay in the organization due to multiple reasons perceived by the employees themselves. It is associated positively with organizational citizenship behaviors and negatively with turnover cognitions. One important thing in this model is the concentration on the employee where the employee is attempting to link his goals with the goals of the organization which is known as goal congruence (Aryee et al., 2005).

\subsubsection{Continuance Commitment}

Continuance commitment occurs when an employee remains in organization because there are largely out of need, as lack of alternatives or costs associated with leaving, such aslost income, or an inability to transfer skills and education to another organization are the primary antecedents of continuance commitment (Meyer et al., 2002). Continuance commitment is more focused on the analysis of the gains and losses that are associated with the turnover, it is logical to assume that this restriction of options facing a choice to stay in organization. An indi vidual perceives the leaving of an organization a very costly, which can deprive him of the relations he or she had in the organization, social costs with the decrease the loyalty of the person and high cost of getting a new job so there is clear that too much costs are associated with the leaving an organization (Amble, 2006).

\subsubsection{Normative Commitment}

Normative commitment is more emotional and sense of liability based model as compared to the other than two models discussed above. The basis of this model is different from the other two models and results in a more positive way for the organization. Meyer and Allen

(1997) explain normative commitment as "a feeling of obligation to continue employment". The employees feeling of moral obligation to stay in the organization because they feel that the organization has spent a lot of the resources in the grooming and the teachings of the employee. Which has put a liability on the employee to work for the organization in the course of achievement of its objectives. The employees perceive themselves as owe the organization to be loyal and work in achievement of the organizational objectives (Batt and Valcour, 2003). So, factors such as; organizational socialization, a feeling of indebtedness, and need for reciprocity force employees to be loyal and committed with the organization (Meyer and Allen, 1991).

\subsubsection{Intention to leave}

The increasing turnover has become the most critical issue in the organizations. Once the intention is created, it 
further develops, as long as the circumstances are not changed to favorable situation. This intention is called intention to leave which is a state of mind where the person want to quit current working at a place in the consideration of getting the other one in the near future.

The most important and immediate antecedent of turnover is the intention to quit (Elangovan, 2001). That drives the most researchers to focus on turnover intention rather than actual turnover. The desire to leave the workplace and the intent to quit are considered a strong indicator of labor turnover (Griffeth et al., 2000).

There are several definitions being introduced for intention to leave. According to Barak et al. (2001) intention to leave means that a serious consideration of leaving the job at present. Meyer et al. (2002) justified turnover intention as deliberate intent was already taken to leave the organization to find other alternatives in other organizations. Aiken et al. (2002) defined it as a prediction of the future behavior because the intent is linked with the future action, which is based on the behavior so it is very much integrated definition. It is clear that there have been similarities in the definitions being proposed by the plenty of researchers.

\subsubsection{Working Women in Jordan}

Jordanian women reinforced their presence and participation in the field of economy and labor. The employment statistical data in Jordan indicated that the participation rate of women aged 15 years and over has increased from $12.3 \%$ in 2002 to $14.9 \%$ in 2009 . While

the rate of unemployment among female rose from $19.9 \%$ in 2004 to $26 \%$ in 2010 despite the high proportion of educated females in Jordan.

Jordan human development report (2011) depicted that the Middle East and North Africa (MENA) territory women make over $28 \%$ of the total labor force which is very less compared to the figure of $43 \%$ in the developing countries on average. Jordanian Workers Observatory believes that the lack of tangible progress in the role of women economically is due mainly to the repellant working conditions afflicting the Jordanian labor market such as; long or irregular or non-elastic working hours, increased workloads, conflicts between people at work, travel for long periods, job movements, presence of uncooperative supervisor or work in a non-supportive organization (Abu Raddaha et al., 2012).

Generally, in the MENA area, the women in the private sector face challenges, such as; social habits the lack of chance to get worthy jobs, lack of training and the money designated for that aim, restriction on movements and discrimination in the workplace. The participation of women in the labor force is much less than men. Besides, the rate of females possessing degrees, but still unemployed is three times more than males. This means wastage of the resources. The advancement of the Jordanian female in academic perspective as compared to the males has been of no use since the wage difference based on gender still prevails. Another matter of regret is the fact that the labor market does not consider that men are paid more than the women, regardless the education level (Jordan human development report, 2011).

In summary, the report displays the fact that men as employee are preferred more in the Jordanian labor market for some reasons such as their ability to work for more and extensively long hours, no household duty is attached to them and they can stay outside home for a longer period. On the other hand, women in Jordan opt for lesser physical and lesser travelling jobs, which keep them closer to their houses. Female prefer to work within the territory closer to their houses so that work and family could be managed.

\subsection{Previous Studies}

Kim (2014), “Work-Life Balance and Employees'Performance: The Mediating Role of Affective Commitment”.

The study examined how work-life balance can affect the affective commitment and in-role performance in Korea. Furthermore it was examined the role of affective commitment in work-life balance and in-role performance. 520 questionnaires were distributed among the industrial workers in Korea, among them 293 contained valid responses. using structural equation modeling (SEM) and regression analysis to reach the objectives. From the analysis, the study concluded that there is a direct relationship between work-life balance with affective commitment but not with in-role performance. However, affective commitment can affect the in-role performance and hence, there is an indirect relationship between work-life balance and in-role performance.

Padma and Reddy (2013), "Work Life Balance: Women Police Constables".

The study examined the relationship between demographic features of women police constables with their work life balance in India. The study also aimed to find out the demographic factors that affect the work life balance of women police in India. 56 police constables were taken as sample for data collection, from whom required data 
was collected using a structured questionnaire. To accomplish the study objectives, Percentages, Factor Analysis, One Sample t-test and ANOVA tests were used. The study identified three factors named Family issues, Personal care issues and Work issues that affect work life balance.

Lee et al. (2013), "Predicting Quality of Work Life on Nurses' Intention to Leave".

The research examined the relationship between quality of work life and nurses' intention to leave their organization in Taiwan. The sample of the study was 1283 nurses from seven hospitals, which was selected through purposive sampling. Data on demographic feature, intention to leave organization and others was collected through a questionnaire, to analyze. The study used Descriptive analysis, Pearson's correlations, and the ordinal regression model to reach the findings. The study found that individual related features such as marital status, education level etc. and work related features such as Work unit and teaching hospital are correlated with nurses' intention to leave their organization.

\section{The Study's Hypotheses}

The study hypotheses were formulated as follows:

H01: There is no significant relationship between work-life balance and intention to leave among working women in KAUH.

H02: There is no significant relationship between work-life balance and organizational (affective continuance and normative) commitment among working women in KAUH.

H03: There is no significant relationship between organizational (affective, continuance, and normative) commitment and intention to leave among working women in KAUH.

H04: Organizational (affective, continuance and normative) commitment are not mediating the relationship between work-life balance and intention to leave among working women in KAUH.

\subsection{The Study Model}

Based on previous literature, the following model is developed to discuss the relationship between work-life balance and intention to leave in KAUH (Figure 1). In this model the independent variable is (work-life balance), the dependent variable is (intention to leave). While the mediating variable is (organizational commitment).

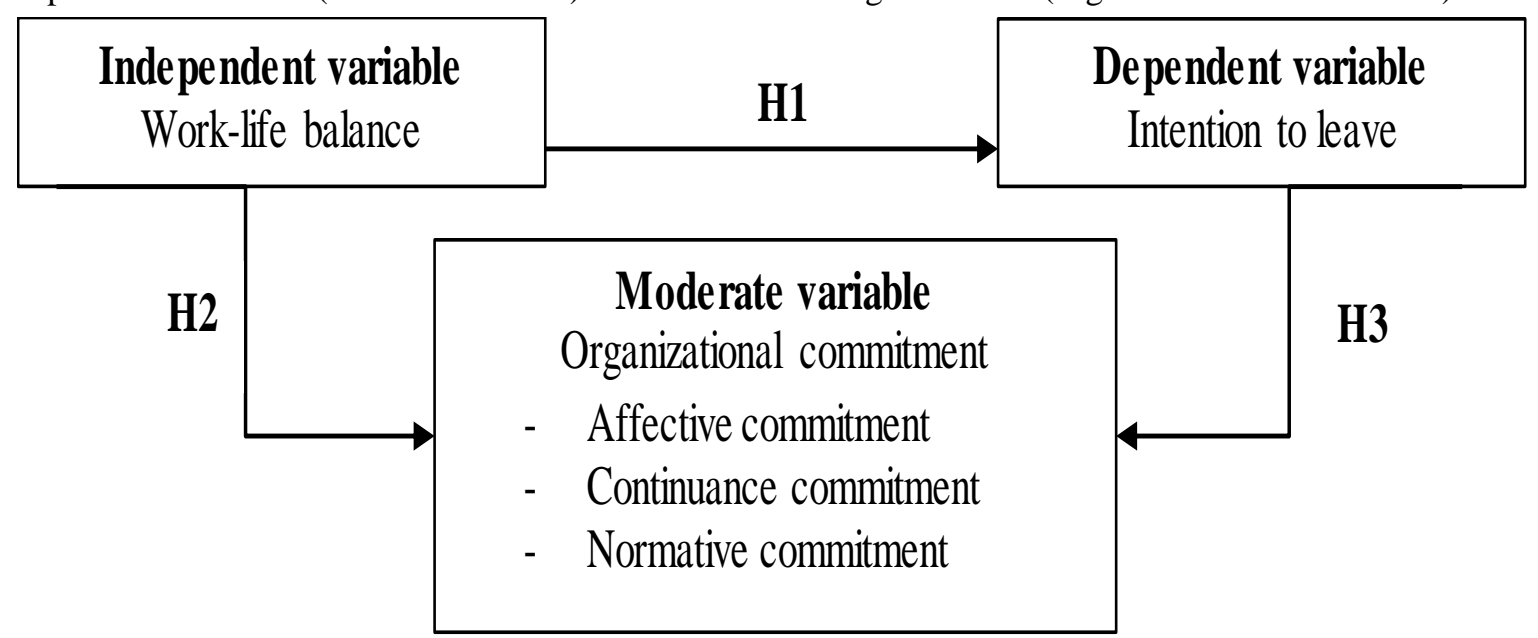

Figure1. Research model based on theoretical framework

\subsection{Research Methodology}

\subsubsection{Sample and Data Source}

The target population of this study is the female employees in KAUH, which was approximately (800) working females at the time of the study (according to KAUH human resource department). The sample frame comprised of working women in KAUH at all degree levels, all departments, single and married, with at least one year experience of being employed with KAUH. The sample of the current study consists of 200 employees, which represent $25 \%$ of the study population. In this study, working women were chosen as a unit of analysis to achieve the goal of this study.

Out of (200) distributed questionnaires (160) were completed and returned. Then, 16 questionnaires were excluded because of many missing information. Hence, (144) fully answered questionnaires were remained and furthered used for analysis, yielded a response rate of $(72 \%)$. 


\subsubsection{Survey Instrument}

Based on previous studies and empirical review, a questionnaire was developed to explore the relationship between the work-life balance, organizational commitment and intention to leave using a sample of female employees in KAUH.The questionnaire items were extracted from previous studies as shown in Table 1.

Table 1 . The sources of the research variables

\begin{tabular}{cc}
\hline Variable & Source \\
\hline Work-life balance & Hayman (2005) \\
Organizational commitment & Meyer et al. (1993) \\
Intention to leave & Miller (2007) \\
\hline
\end{tabular}

After developing the questionnaire in English language, the questionnaire was translated to Arabic language and then back translated to ensure that the measures were translated correctly. Then, three business academics at Yarmouk University reviewed the questionnaire in both languages. Some changes were done according to the academic recommendations to get more clarity on the questionnaire wording. All constructs were measured using five-point scale (Likert type) that ranged from (5) which refers to the highest degree, to (1) which refers to the lowest degree. The final form of questionnaire was a 4 pages questionnaire in Arabic or English comprised from two sections: The first section: Demographics: The demographic section was used to identify the characteristics of the respondent (age, years of experience, job position, academic level, current marital status , number of children ) for descriptive purposes. The second section: Questionnaire main body: This section includes the three variable dimensions: (2) dimensions of work-life balance (11 questions), (3) dimensions of organizational commitment (18 questions), and intention to leave (6 questions).

\subsubsection{Statistical Tools}

The Statistical Package for Social Science (SPSS) version 20.0 was used to analyze the survey data. Several types of statistical analysis have been performed; simple regression analysis used to test the main variables, and path analysis used to test the effect of moderate variable.

\subsubsection{Validity and Reliability}

To examine the validity of the survey and to ensure no biases with multiple interpretations or inappropriate and unclear wording, the items of the survey instrument were extracted from previous studies, translated from English to Arabic then back translated and evaluated by three academics in business administration. Their comments and recommendations were taken into consideration to improve some of the questionnaire items in a manner that fits the study.

Reliability of the survey construct was established by calculating Cronbachs' Alpha coefficient .Obtaining ( $\alpha \geq$ 0.60 ) considered in practice for management science and Humanities is acceptable in general (Sekaran and Bougie, 2003). Table (2) shows the results of Cronbachs Alpha for each dimension. As illustrates in Table (2), all variables show satisfactory value of reliability. The reliability coefficient for the main content of the questionnaire values ranged between (0.69) and (0.87), hence it is acceptance values.

Table 2. Cronbachs' Alpha coefficient results

\begin{tabular}{cccc}
\hline Measured Variable & Dimensions & No. of items & Cronbachs' Alpha coefficient \\
\hline \multirow{2}{*}{ Work-life balance } & $\begin{array}{c}\text { Work interference with } \\
\text { personal life }\end{array}$ & 7 & 0.87 \\
& Personal life interference & 4 & 0.71 \\
\hline \multirow{3}{*}{ with work } & Affective commitment. & 6 & 0.80 \\
& Continuance commitment. & 6 & 0.78 \\
\hline Intention to leave & Affective commitment. & 6 & 0.79 \\
\hline
\end{tabular}

\section{Results and Analysis}

\subsection{Demographic Characteristic of the Sample}

Six demographic characteristics were included in this study (age, educational level, marital status, position, years of experience, and the number of children). The descriptions of demographic statistics are shown in Table (3). The majority of the sample $(69.5 \%)$ is less than 35 years of age. The percentage of bachelor degree respondents was $(58.3 \%)$ which is more than other respondents who have Diploma, Master and Doctorate $(20.8 \%, 18.1 \%$, and $2.8 \%$ respectively). Table 3 also shows that the majority of the sample are married with $74.3 \%$.

Most of the respondents work in nursing, which is normal, because the number of women who work in nursing exceed other positions. More than half of respondents having 5 years' experience and more. Almost half of the 
sample doesn't have kids or they have one child only which may indicate that organizations in Jordan favored non mother working women or mothers with more than one child prefer to stay home (Descriptive analysis ).

The descriptive statistics are shown in Table (4). The mean of all the variables came moderately (close to three). The level of work-life balance is medium, with a mean scores of work-life balance equals to $(\mathrm{M}=3.40)$ and standard de viation $(\mathrm{SD}=0.83)$. The mean score of work-life balance two dimensions are $(\mathrm{M}=3.76)$ and $(\mathrm{M}=1.87)$ which means that the respondents goes with work interference with personal life dimension of work-life balance. The level of organizational commitment is medium $(\mathrm{M}=3.32)$ and $(\mathrm{SD}=0.54)$, and the level of intention to leave is medium too $(\mathrm{M}=3.32)$ and $(\mathrm{SD}=0.78)$.

Table 3. Sample descriptive characteristics $(\mathrm{n}=144)$

\begin{tabular}{|c|c|c|c|}
\hline Demographic elements & Category & Frequency & Percentage $(\%)$ \\
\hline \multirow{4}{*}{ Age } & Less than 25 & 20 & 13.9 \\
\hline & 25- less than 35 & 80 & 55.6 \\
\hline & 35- less than 45 & 34 & 23.6 \\
\hline & 45 years and more & 10 & 6.9 \\
\hline \multirow{4}{*}{ Educational level } & Diploma & 30 & 20.8 \\
\hline & Bachelor & 84 & 58.3 \\
\hline & Master & 26 & 18.1 \\
\hline & Professional degree (Doctorate) & 4 & 2.8 \\
\hline \multirow{4}{*}{ Marital status } & Single & 34 & 23.6 \\
\hline & Married & 107 & 74.3 \\
\hline & Divorced & 1 & 0.7 \\
\hline & Widowed & 2 & 1.4 \\
\hline \multirow{4}{*}{ Position } & Physician & 30 & 20.8 \\
\hline & Nurse & 67 & 46.5 \\
\hline & Managerial employee & 31 & 21.5 \\
\hline & Others & 16 & 11.1 \\
\hline \multirow{3}{*}{ Years of experience } & Less than 5 & 55 & 38.2 \\
\hline & 5- less than 10 & 36 & 25.0 \\
\hline & 10 years and more & 53 & 36.8 \\
\hline \multirow{4}{*}{ Number of children } & None & 49 & 34.0 \\
\hline & One child & 17 & 11.8 \\
\hline & Tow Childs & 29 & 20.1 \\
\hline & Three Childs and more & 49 & 34.0 \\
\hline \multicolumn{4}{|c|}{ Table 4. Descriptive Statistics for sample size $(n=144)$} \\
\hline Measured V & $\mathrm{n}$ & M & SD \\
\hline Work-life $b c$ & 144 & 3.40 & 0.83 \\
\hline Work interference wi & 1 life & 3.76 & 0.91 \\
\hline Personal life interfere & work & 1.87 & 0.47 \\
\hline Organizational $\mathrm{c}$ & 144 & 3.32 & 0.54 \\
\hline Affective com & 144 & 3.12 & 0.71 \\
\hline Continuance cor & 144 & 3.55 & 0.78 \\
\hline Affective com & 144 & 3.28 & 0.76 \\
\hline Intention to & 144 & 3.32 & 0.78 \\
\hline
\end{tabular}

Before conducting regression analysis skewedness and Kurtosis of the data was checked to ensure normality. The results of skewedness and Kurtosis showed that none of the data set deviated from $(Z= \pm 1.96)$.

\subsubsection{The test of the First Hypothesis}

Simple regression was used to test whether work-life balance predicts participant's intention to leave. The result of this test shown in Table (5). According to Table (5), the effect of work-life balance on intention to leave among working women in KAUH is significant at level $(\alpha \leq 0.05)(\mathrm{Sig}=0.000)$, this means that the work-life balance affects the intention to leave among working women in KAUH. Based on this analyzing $\mathrm{H} 01$ is rejected. The $\beta$ coefficient (Regression coefficient) equal to $(\beta=0.355)$. The positive sign for $\beta$ coefficient indicate a positive relationship between the two variables. Which means that; increasing in one unit in work-life balance will increase in the level of intention to leave among working women in KAUH. The results also indicated that work-life balance explained $11.5 \%$ of the variance in the intention to leave $\left(\mathrm{R}^{2}=0.115\right)$. 
Table 5. Simple regression test for the influence of work-life balance on intention to leave $(n=144)$

\begin{tabular}{ccccccccc}
\hline Independent Variable & $\boldsymbol{\beta}_{\text {constant }}$ & $\boldsymbol{\beta}_{\text {coefficient }}$ & $\mathbf{R}$ & $\mathbf{R}^{\mathbf{L}}$ & $\mathbf{| t |}$ & Sig. & $\mathbf{F}$ & Sig. \\
\hline Work-life balance & 2.135 & 0.355 & 0.339 & 0.115 & 4.298 & $0.000^{*}$ & 18.477 & $0.000^{*}$ \\
\hline Dependent variable: Intention to leave $(*$ significant level $\leq 0.05)$ & & & & & \\
\hline
\end{tabular}

Simple regression was used to test whether work-life balance predicts participant's (affective, continuance and normative) commitment, the results of the tests are shown in Table (6). According to Table (6), the effect of work-life balance on (affective and normative) commitment among working women in KAUH is significant at level $(\alpha \leq 0.05)(\mathrm{Sig} .=0.000)$ and $(\mathrm{Sig} .=0.043)$ respectively. While the effect of work-life balance on continuance commitment among working women in KAUH is not significant at level $(\alpha \leq 0.05)$ ( $\mathrm{Sig}=0.650)$. This means that the work-life balance affects the (affective and normative) but does not affect normative commitment among working women in KAUH. Based on this results $\mathrm{H} 02$ is rejected for both (affective and normative) commitment and accepted for continuance commitment.

The results showed that $\beta$ coefficient for both (affective and normative) commitment equal to $(\beta=-0.705)$ and $(\beta=$ $-0.194)$ respectively. The negative sign for $\beta$ coefficient indicates a negative relationship between independents and dependent variables. While $\beta$ coefficient for continuance commitment equal to $(\beta=0.045)$. The positive sign for $\beta$ coefficient indicates a positive relationship between independent and dependent variables. The results also indicated that work-life balance explained $33.6 \%$ of the variance in affective commitment $\left(R^{2}=0.336\right)$, whereas it explained $0.1 \%$ of the variance in continuance commitment $\left(\mathrm{R}^{2}=0.001\right)$ and it explained $2 \%$ of the variance in normative commitment $\left(\mathrm{R}^{2}=0.020\right)$

Table 6. Simple regression test for the influence of work-life balance on organizational commitment $(n=144)$

\begin{tabular}{ccccccccc}
\hline Dependent variable & $\beta_{\text {constant }}$ & $\beta_{\text {coefficient }}$ & $\mathrm{R}$ & $\mathrm{R}^{2}$ & $\mathrm{It} \mid$ & Sig. & $\mathrm{F}$ & Sig. \\
\hline Affective commitment & 5.297 & -0.705 & 0.579 & 0.336 & 8.468 & $0.000^{*}$ & 71.714 & $0.000^{*}$ \\
Continuance commitment & 3.193 & 0.045 & 0.038 & 0.001 & 0.455 & 0.650 & 0.207 & 0.650 \\
Normative commitment & 3.845 & -0.194 & 0.169 & 0.02 & 2.044 & 0.043 & 4.176 & 0.043 \\
\hline Independent variable: Intention to leave (* significant level $\leq 0.05)$ & & & & &
\end{tabular}

\subsubsection{The Test of the Third Hypothesis}

Simple regression was used to test whether participant's (affective, continuance and normative) commitment predicts participant's intention to leave. The results of the tests are shown in Table (7).According to Table (7), the effect of (affective, continuance and normative) commitment on intention to leave among female employees in KAUH is significant at level $(\alpha \leq 0.05)(\mathrm{Sig} .=0.000),(\mathrm{Sig} .=0.004)$ and $(\mathrm{Sig} .=0.009)$ respectively. This means that (affective, continuance and normative) commitment affects intention to leave among working women in KAUH. Based on this results $\mathrm{H} 03$ is rejected. The results showed that $\beta$ coefficient for (affective, continuance and normative) commitment equal to $(\beta=-0.334),(\beta=-0.211)$ and $(\beta=-0.198)$. The negative sign for $\beta$ coefficient indicate a negative relationship between independents and dependent variables.

The results also indicated that affective commitment explained $15.2 \%$ of the intention to leave $\left(\mathrm{R}^{2}=0.152\right)$. While continuance commitment explained $5.8 \%$ of the variance in the intention to leave $\left(\mathrm{R}^{2}=0.058\right)$. Finally, normative commitment explained $4.7 \%$ of the variance in the intention to leave $\left(R^{2}=0.047\right)$.

Table 7. Simple regression test for the influence of organizational commitment on intention to leave $(n=144)$

\begin{tabular}{ccccccccc}
\hline Independent variable & $\beta_{\text {constant }}$ & $\beta_{\text {coefficient }}$ & $\mathrm{R}$ & $\mathrm{R}^{2}$ & |t| & Sig. & $\mathrm{F}$ & Sig. \\
\hline Affective commitment & 4.31 & -0.334 & 0.389 & 0.152 & 5.038 & $* 0.000$ & 25.38 & $* 0.000$ \\
Continuance commitment & 4.046 & -0.211 & 0.24 & 0.058 & 2.944 & $* 0.004$ & 8.664 & $* 0.004$ \\
Normative commitment & 3.97 & -0.198 & 0.217 & 0.047 & 2.654 & $* 0.009$ & 7.042 & $* 0.009$ \\
\hline
\end{tabular}

Independent variable: Intention to leave $(*$ significant level $\leq 0.05)$

5.2.4 The Test of the Fourth Hypothesis

In order to test the fourth hypothesis, structural analysis (path analysis) has been used. The results are presented in Table (8). As illustrated in the Table (8), the Sig. value, for mediation effects of affective commitment in the relationship between work-life balance and intention to leave, turn out to be insignificant ( $\mathrm{Sig}$. $=0.071$ ); this means that affective commitment fully mediates the relation. While the Sig. value, for mediation effects of normative commitment in the relationship between work-life balance and intention to leave, turn out to be significant (Sig. = 0.000 ); this means that normative commitment partially mediates the relationship between work-life balance and intention to leave. So, Hypothesis 04 is rejected for both affective and normative commitment.

Because the result of regression test for the relationship between work-life balance and continuance commitment was not significant the dimension (continuous commitment) excluded from path analysis. 
Table 8. Path analysis for the mediating effect of normative commitment between work-life balance and intention to leave

\begin{tabular}{|c|c|c|c|c|c|c|c|c|}
\hline The mediator & Predictors & $\begin{array}{c}\text { Dependent } \\
\text { variable }\end{array}$ & $B_{\text {coefficient }}$ & $\mathbf{R}^{2}$ & $|\mathbf{t}|$ & Sig. & $\mathbf{F}$ & Sig. \\
\hline \multirow{3}{*}{$\begin{array}{c}\text { Affective } \\
\text { commitment }\end{array}$} & Work-life balance & $\begin{array}{c}\text { Affective } \\
\text { commitment }\end{array}$ & -0.705 & 0.336 & 8.468 & $0.000^{*}$ & 71.714 & 0.000 \\
\hline & Work-life balance & Intention to leave & 0.355 & 0.115 & 4.298 & $0.000^{*}$ & 18.477 & 0.000 \\
\hline & $\begin{array}{c}\text { Work-life balance }+ \\
\text { Affective commitment }\end{array}$ & Intention to leave & 0.179 & 0.171 & 1.82 & 0.071 & 14.553 & 0.000 \\
\hline \multirow{3}{*}{$\begin{array}{l}\text { Normative } \\
\text { commitment }\end{array}$} & Work-life balance & $\begin{array}{c}\text { Normative } \\
\text { commitment }\end{array}$ & -0.194 & 0.029 & -2.044 & $0.043^{*}$ & 4.176 & 0.043 \\
\hline & Work-life balance & Intention to leave & 0.355 & 0.115 & 4.298 & $0.000^{*}$ & 18.477 & 0.000 \\
\hline & $\begin{array}{l}\text { Work-life balance }+ \\
\text { Normative commitment }\end{array}$ & Intention to leave & 0.325 & 0.141 & 3.934 & $0.000^{*}$ & 11.62 & 0.000 \\
\hline
\end{tabular}

\section{Discussion}

The tests of the first hypothesis showed that there is a significant and positive relationship between work-life balance and intention to leave, this means that the working women who have a balance between life and work have intention to leave work, which considered contradictory result. Looking back to our measures of work-life balance and the results of Table (4) can tell that the respondents believe that their work interference with their personal life not the opposite. Which means that this result can be explained by the fact the respondents believe that at any point of time when their work interfere with their personal life their intention to leave the organization will become inevitable. The low value of $\mathrm{R}^{2}\left(\mathrm{R}^{2}=11.5 \%\right)$ indicates that there another factors rather than the work-life balance influencing intention to leave. These results are similar to previous studies of (Huang et al., 2007) and Noor (2011).

While the test of the second hypothesis showed that there are significant relationship between work-life balance and (affective and normative) commitment but not with continuance commitment. Also, the results showed a negative relation between work-life balance and (affective and normative) commitment. This result can be explained by the fact that the respondents believe that their work interference with their personal life will decrease their loyalty, and goal congruence Sakthivel and Jayakrishnan (2012). Similar result of the relationship between work-life balance and continuance commitment was achieved by Kinnoin (2005) study. Finally, this study finding of the relationship between work-life balance and normative commitment is consistent with Turnley and Feldman(1999) findings. The results of $\mathrm{R}^{2}$ showed that affective commitment has the highest $\mathrm{R}^{2}$ compared with the other two commitment models. Which means that work-life balance explained most of the variance in the affective commitment.

Whereas the test of the third hypothesis showed that the relationship between the three models of commitment (affective, normative and continuance) and intention to leave were significant and negative. This result can be explained by the fact that; loyal and more attached employees with a consistent personal and organizational objectives will definitely decrease employee's intention to leave the organization. Add to this, the results showed that affective commitment explains only (15.2\%) of the variance in intention to leave, which was the highest $\mathrm{R}^{2}$ among other models of commitment. This indicates that other factors affect this relation. The study of Kamel (2013) showed similar results of this study regarding the relationship between affective commitment and intention to leave.

Finally, path analysis that used to test the Forth hypothesis revealed that affective commitment fully mediate the relation between work-life balance and intention to leave while normative commitment partially mediates this relation. This result implies that the care granted from the organizations to their employees to de velop them and to help them to reach their personal objectives with regard that their work not interfere with their personal lifeis not the only things that can guarantee that employees have no intention to leave. But parallel objectives that can be found between employees and their organizations with no interfere of their job with their personal life can guarantee that employees will remain in the organization. The full mediation result of affective commitment was supported by Kamel (2013).

\section{Conclusion}

As stated earlier, the aim of this research is to investigate the mediating effect of organizational commitment on the relationship between work-life balance and intention to leave among working women in KAUH.

This study raised a number of questions, and de veloped hypotheses related to the study variables. The study 
reached many results that contributed to solve the study problem, ans wer the study questions and its hypotheses. The main results can be summarized as follows:

1. There was a significant relationship between work-life balance and intention to leave among working women in KAUH.

2. There was a significant relationship between work-life balance and (affective and normative) commitment, but the relationship was not significant with continuance commitment among working women in KAUH.

3. There was a significant relationship between (affective, continuance and normative) commitment and intention to leave among working women in in KAUH.

Affective commitment has fully mediated the relationship between work-life balance and intention to leave, while normative commitment has partially mediated the relationship between work-life balance and intention to leave among working women in KAUH.

\section{Recommendations}

Based on the study results the researcher suggests the following recommendations:

1. The Jordanian hospitals should adopt work-life balance program, to improve the motivation and commitment of women employees for better organizational performance. The recommended programs as safety, reward, promotion, flexible hour, training, payment, childcare support, and parental leave.

2. Provide work-life balance program is necessary for women in Jordanian hospitals to increase job satisfaction that leads to enhance commitment for organization and reduce intention to leave The Jordanian hospitals can improve the financial support like salary level for employee to reduce the intention to leave.

3. The organizations must enhance the participation of employee in decision making and locus of control to improved organization commitment.

4. Organization should give special attention to commitment its vision and goals in such a way that is consistent with the employee values to enhance affective commitment.

5. Mangers should give special attention to the level of organizational commitment since it has a significant effect on intention to leave. The Jordanian hospitals can improve the financial support like salary level for employee to reduce the intention to leave.

6. The organizations must enhance the participation of employee in decision making and locus of control to improved organization commitment.

7. Organization should give special attention to commitment its vision and goals in such a way that is consistent with the employee values to enhance affective commitment.

Mangers should give special attention to the level of organizational commitment since it has a significant effect on intention to leave.

\section{References}

Aamir, A., Hamid, A. B. A., Haider, M., \&Akhtar, C. S. (2016). Work-life balance, job satisfaction and nurses retention: moderating role of work volition. International Journal of Business Excellence, 10(4), 488-501. https://doi.org/10.1504/IJBEX.2016.079257

Abu Raddaha, A. H., Alasad, J., Albikawi, Z. F., Batarseh, K. S., Realat, E. A., Saleh, A. A., \& Froelicher, E. S. (2012). Jordanian nurses' job satisfaction and intention to quit. Leadership in Health Services, 25(3), 216-231. https://doi.org/10.1108/17511871211247651

Aiken, L. H., Clarke, S. P., \& Sloane, D. M. (2002). Hospital staffing, organization, and quality of care: cross-national findings. Nursing outlook, 50(5), 187-194.https://doi.org/10.1067/mno.2002.126696

Allen, N. J., \& Meyer, J. P. (1990). The measurement and antecedents of affective, continuance and normative commitment to the organization. Journal of Occupational Psychology, 63(1), 1-18. https://doi.org/10.1111/j.2044-8325.1990.tb00506.x

Amble, B. (2006). Work- life balance becoming critical to recruitment and retention. Management Issues. Retrieved on September 24, 2014.

Aryee, S., Srinivas, E. S., \& Tan, H. H. (2005). Rhythms of life: antecedents and outcomes of work-family balance in employed parents. Journal of Applied Psychology, 90(1), 132-146.

https://doi.org/10.1037/0021-9010.90.1.132 
Barak, M. E. M., Nissly, J. A., \& Levin, A. (2001). Antecedents to retention and turnover among child welfare, social work, and other human service employees: What can we learn from past research? A review and metanalysis. Social Service Review, 75(4), 625-661. https://doi.org/10.1086/323166

Batt, R., \& Valcour, P. M. (2003). Human resources practices as predictors of work-family outcomes and employee turnover. Industrial Relations: A Journal of Economy and Society, 42(2), 189-220. https://doi.org/10.1111/1468-232x.00287

Biller, H. B. (1993). Fathers and families: Paternal factors in child development. Westport, CT: Auburn House.

Botsford, W. E. (2009). Psychological contracts of mothers: Does breach explain intention to leave the workforce? Doctoral Thesis, George Mason University, United States.

Chaaban, H. A. (2006). Job satisfaction, organizational commitment and turnover intent among nurse anesthetists in Michigan. Thesis Abstracts International, 67(01), (UMI No. 3206380).

Clark, S. C. (2001). Work cultures and work/family balance. Journal of Vocational Behavior, 58(3), 348-365. https://doi.org/10.1006/jvbe.2000.1759

Elango van, A. R. (2001). Causal ordering of stress, satisfaction and commitment, and intention to quit: a structural equations analysis. Leadership \& Organization Development Journal, 22(4), 159-165. https://doi.org/10.1108/01437730110395051

Elizur, D., \& Koslowsky, M. (2001). Values and organizational commitment. International Journal of Manpower, 22(7), 593-599. https://doi.org/10.1108/01437720110408967

Felstead, A., Jewson, N., Phizacklea, A., \& Walters, S. (2002). Opportunities to work at home in the context of work-life balance. Human resource management journal, 12(1), 54-76. https://doi.org/10.1111/j.1748-8583.2002.tb00057.x

Greenhaus, J. H., \& Beutell, N. J. (1985).Sources of conflict between work and family roles. Academy of management review, 10(1), 76-88.

Griffeth, R. W., Hom, P. W., \& Gaertner, S. (2000). A meta-analysis of antecedents and correlates of employee turnover: Update, moderator tests, and research implications for the next millennium. Journal of management, 26(3), 463-488. https://doi.org/10.1177/014920630002600305

Guest, D. E. (2001). Perspectives on the study of work-life balance. A discussion paper prepared for the 2001 ENOP Symposium, Paris, March 29-31. Retrieved on August 4, 2016.

Hattar-Pollara, M., \& Dawani, H. (2006).Cognitive appraisal of stress and health status of wage working and nonwage working women in Jordan. Journal of Transcultural Nursing, 17(4), 349-356. https://doi.org/10.1177/1043659606291543

Hayman, J. (2005). Psychometric assessment of an instrument designed to measure work-life balance. Research and Practice in Human Resource Management, 13(1), 85-91.

Hill, E. J., Martinson, V. K., Ferris, M., \& Baker, R. Z. (2004). Beyond the mommy track: The influence of new concept part time work for professional women on work and family. Journal of Family and Economic Issues, 25(1), 121- 136. https://doi.org/10.1023/B:JEEI.0000016726.06264.91

Huang, T. C., Lawler, J., \& Lei, C. Y. (2007).The effects of quality of work life on commitment and turnover intention. Social Behavior and Personality: an international journal, 35(6), 735-750. https://doi.org/10.2224/sbp.2007.35.6.735

Jordan human de velopment report.(2011). Ministry of planning and international cooperation publication, Jordan. Retrieved on December 10, 2016.

Kamel, M. M. (2013). The mediating role of affective commitment in the relationship between quality of work life and intention to leave. Life Science Journal, 10(4), 1062-1067.

Kaur, A. (2004). Costed not valued: Women workers in industrialising Asia. New York: Palgrave Macmillan. https://doi.org/10.1057/9780230596702

Khatri, N., Budhwar, P., \& Fern, C. T. (1999). Employee turnover: bad attitude or poor management. Nanyang Technological University, Singapore, 12-99.

Kim, H. K. (2014). Work-Life Balance And Employees' Performance: The Mediating Role Of Affective Commitment. Global Business And Management Research: An International Journal, 6(1), 37-51. Retrieved From www.gbmr.Ioksp.com 
Kinnoin, C. M. (2005).An examination of the relationship between family-friendly policies and employee job satisfaction, intent toleave, and organizational commitment. Doctoral Thesis, Nova Southeastern University, United States.

Lakshmi, K. S., \& Gopinath, S. S. (2013). Work-life balance of women employees-with reference to teaching faculties. Abhinav International Monthly Refereed Journal of Research In Management \& Technology, 2(2320-0073 2013), 53-62.

Lee, Y. W., Dai, Y. T., Park, C. G., \& McCreary, L. L. (2013).Predicting quality of work life on nurses' intention to leave. Journal of Nursing Scholarship, 45(2), 160-168. https://doi.org/10.1111/jnu.12017

Lyness, K. S., \& Judiesch, M. K. (2008). Can a manager have a life and a career? International and multisource perspectives on work-life balance and career advancement potential. Journal of Applied Psychology, 93(4), 789-805.https://doi.org/10.1037/0021-9010.93.4.789

Meyer, J. P., \& Allen, N. J. (1997). Commitment in the workplace: theory, research, and application. Sage publications. California.

Meyer, J. P., \& Herscovitch, L. (2001). Commitment in the workplace: Toward a general model. Human Resource Management Review, 11(3), 299-326.https://doi.org/10.1016/S1053-4822(00)00053-X

Meyer, J. P., Allen, N. J., \& Smith, C. A. (1993). Commitment to organizations and occupations: Extension and test of a three-component conceptualization. Journal of Applied Psychology, 78(4), 538. https://doi.org/10.1037/0021-9010.78.4.538

Meyer, J. P., Stanley, D. J., Herscovitch, L., \& Topolnytsky, L. (2002). Affective, continuance, and normative commitment to the organization: A meta-analysis of antecedents, correlates, and consequences. Journal of vocational behavior, 61(1), 20-52. https://doi.org/10.1006/jvbe.2001.1842

Meyer, J., \& Allen, N. (1991). A three-component conceptualization of organizational commitment. Human Resource Management Review, 1(1), 61-89. https://doi.org/10.1016/1053-4822(91)90011-Z

Miller, P. E. (2007). The relationship between job satisfaction and intention to leave: A study of hospice nurses in a for-profit corporation. Doctoral Thesis, Capella University, United States.

Ng, T. W., Sorensen, K. L., \& Eby, L. T. (2006). Locus of control at work: a meta-analysis. Journal of organizational Behavior, 27(8), 1057-1087.

Noor, K. M. (2011). Work-life balance and intention to leave among academics in Malaysian public higher education institutions. International journal of business and social science, 2(11), 240-248.

Owusu-Poku, I. (2014). Work-life balance and health of women: A qualitative study of a mining company in Ghana. Master Thesis, University of Bergen, Bergen.

Padma, S., \& Reddy, S. (2013, October-December). Work Life Balance: Women Police Constables. SCMS Journal of Indian Management, 39-47.

Ramos, H. M., Francis, F., \& Philipp, R. V. (2015). Work life balance and quality of life among employees in Malaysia. International Journal of Happiness and Development, 2(1), 38-51. https://doi.org/10.1504/IJHD.2015.067598

Rigby, M., \& O'Brien-Smith, F. (2010). Trade union interventions in work-life balance. Work, Employment \& Society, 24(2), 203-220. https://doi.org/10.1177/0950017010362145

Sakthivel, D., \&Jayakrishnan, J. (2012).Work-life balance and organizational commitment for nurses. Asian Journal of Business and Management Sciences, 2(5), 1-6.

Shankar, T., \& Bhatnagar, J. (2010). Work-life balance, employee engagement, emotional consonance/dissonance \& turnover intention. Indian Journal of Industrial Relations, 46(1), 74-87.

Strachota, E., Normandin, P., O’Brien, N., Clary, M., \& Krukow, B. (2003). Reason registered nurses leave or change employment status. Journal of Nursing Administration, 33(2), 111-117. https://doi.org/10.1097/00005110-200302000-00008

Sturges, J., \& Guest, D. (2004).Working to live or living to work? Work/life balance early in the career. Human Resource Management Journal, 14(4), 5-20. https://doi.org/10.1111/j.1748-8583.2004.tb00130.x

Tamkeen fields for aid. (2015). Futures thumbnail study, working women in sectors of secretary, beauty salons, and supportive health services "Ill-treatment and Lack of Protection". 
Tatman, A. W. (2001). Role stressors, Inter role conflict, and well-being: The moderating influence of spousal support and coping behaviors among employed parents, a replicative study. Unpublished research paper, University of Wisconsin-Stout, Menomonie.

Turnley, W. H., \& Feldman, D. C. (1999).The impact of psychological contract violations on exit, voice, loyalty, and neglect. Human relations, 52(7), 895-922. https://doi.org/10.1177/001872679905200703

Vigoda, E., \& Cohen, A. (2003). Work congruence and excellence in human resource management empirical evidence from the Israeli nonprofit sector. Review of Public Personnel Administration, 23(3), 192-216. https://doi.org/10.1177/0734371X03252436

Voydanoff, P. (2005). Toward a conceptualization of perceived work-family fit and balance: a demands and resources approach. Journal of Marriage and Family, 67(4), 822-836.

https://doi.org/10.1111/j.1741-3737.2005.00178.x

\section{Copyrights}

Copyright for this article is retained by the author(s), with first publication rights granted to the journal.

This is an open-access article distributed under the terms and conditions of the Creative Commons Attribution license (http://creativecommons.org/licenses/by/4.0/). 